\title{
Landslide Susceptibility Mapping Using Multiple Regression and GIS Tools in Tajan Basin, North of Iran
}

\author{
Somayeh Mashari eshghabad ${ }^{1}$, Karim Solaimani ${ }^{2} \&$ Ebrahim Omidvar $^{3}$ \\ ${ }^{1}$ Department of Natural Resource, Islamic Azad University, Iran \\ ${ }^{2}$ Natural resource faculty of Sari University of agricultural scienses and natural resources, Iran \\ ${ }^{3}$ Natural resource faculty, University of Mazandaran, Iran \\ Correspondence: Somayeh Mashari eshghabad, Department of Natural Resource, Islamic Azad University, Iran. \\ Tel: 98-915-106-6837. E-mail: mashari1363@gmail.com
}

Received: February 29, 2012 Accepted: March 27, 2012 Online Published: August 20, 2012

doi: 10.5539/enrr.v2n3p43

URL: http://dx.doi.org/10.5539/enrr.v2n3p43

\begin{abstract}
Landslide is a natural hazard that causes many damages to the environment. Depending on the landform, several factors can cause the Landslide. This research addresses the methodology for landslide susceptibility mapping using multiple regression analysis and GIS tools. Based on the initial hypothesis, ten factors were recognized as effectual elements on landslide, which is geology, slope, aspect, distance from roads, faults and drainage network, soil capability, land use and rainfall. Crossing investigated parameters with the observed landslides indicated that three factor including distance from channel network, distance from fault and rainfall have no major effect on observed landslide in Tajan area. In order to quantifying the parameters in the form of weighting factors, the coverage of landslides in different observation was determined. Then Stepwise method was used for statistical analysis. It was found that slope, aspect, distance from the roads and soil capability are as most effective factors in landslide respectively.
\end{abstract}

Keywords: landslide, multivariate regression, GIS, Tajan

\section{Introduction}

Landslide susceptibility can be determined by using comparative analyses of conditions and factors in previously damaged areas. Landslide susceptibility has been the focus of several researchers. Major parameters that often involved in modeling landslide susceptibility are climatic variables that can be analyzed to predict temporal triggering of instabilities (Terlien, 1998; Schmidt \& Beyer, 2003; Casadei et al., 2003). In addition, slope morphology, land use and bedrock lithology are also used in modelling landslide susceptibility (Baeza \& Corominas, 2001; Gorsevski et al., 2006). According to Lee and Min (2001) the main parameter of the slope stability analysis is the slope angle. The slope angle is directly related to the landslides,and frequently used in preparing landslide susceptibility maps (Clerici et al., 2002; Saha et al., 2002; Cevik \& Topal, 2003; Ercanoglu et al., 2004; Lee et al., 2004; Lee, 2005; Yalcin, 2005). Moreover, Landslides may occur near to the roads and on the side of the slopes affected by roads (Pachauri \& Pant, 1992; Pachauri et al., 1998; Ayalew \& Yamagishi, 2005; Yalcin, 2005). Many of the landslides in hilly areas occur due to the erosion associated with drainages. Thus, a drainage network has been used to consider the impact of soil saturation zones on left and right over banks of drainage systems (Saha et al, 2002; Cevik \& Topal, 2003; Yalcin, 2005). Other researchers have investigated on the impact of aspect on landslides (Saha et al., 2002; Cevik \& Topal, 2003; Ercanoglu et al., 2004; Lee et al., 2004a; Yalcin, 2008 ). Refer to the Sinha et al. (1975) south aspects more sensitive to landslide than north aspects. In addition, the related parameters of aspect such as exposure to sunlight, drying winds, rainfall (degree of saturation), and discontinuities may control the landslides (Cevik \& Topal, 2003; Suzan \& Doyuran, 2004; Komac, 2006). It is believed that faults can also be important parameter in landslide. The effect of distance from the faults has been the focus of study by Lee (2007). Morphometric features have also been used to discuss landslide typology (Skempton, 1953; Glenn et al., 2006). Modeling and prediction of geo hazard such as landslide can be accomplished much more efficiently and cost effectively using GIS. During the past decades, many GIS-based approaches have been conducted for quantitative prediction of landslide. (Carrara, 1983; Carrara et al., 1991, 1999; Jade \& Sarkar, 1993; Chung et al., 1995, Chung \& Fabbri, 1999, 2001). It is also common to use multivariate statistics with GIS tools in landslide susceptibility studies (Carrera et al., 1983, 1991, 
1992).

From multivariate analysis, better hypothetical correlation between instability factors and landslide occurrence is perceived and it provides more reliable response (Carrara, 1983; Carrara et al., 1991, 1992; Mark \& Ellen, 1995; Clerici et al., 2002; Ayalew \& Yamagishi, 2004). Multivariate regression analysis plays a central role in statistics that cause one of the most powerful and commonly used techniques. (McCullagh \& Nelder, 1989). However, this approach inherently has some limitations such as generalizing and simplifying of causal factors. In addition, this method does not take into account the temporal aspects of landslides and is not able to predict the impact of changes in the controlling conditions.

\section{Methods and Material}

\subsection{Materials}

\subsubsection{Study Area}

The study region covering $62.07 \mathrm{~km}^{2}$ is located on the southwestern part of Sari the capital of Mazandaran province, Iran. Geographically is located in Tajan basin in the northern Alborz range where is limited between $53^{\circ} 00^{\prime} 12^{\prime \prime} \mathrm{E}$ to $53^{\circ} 06^{\prime} 34^{\prime \prime} \mathrm{E}$ and $36^{\circ} 20^{\prime} 48^{\prime \prime} \mathrm{N}$ to $36^{\circ} 27^{\prime} 50^{\prime \prime} \mathrm{N}$. This study was completed during summer of 2008.

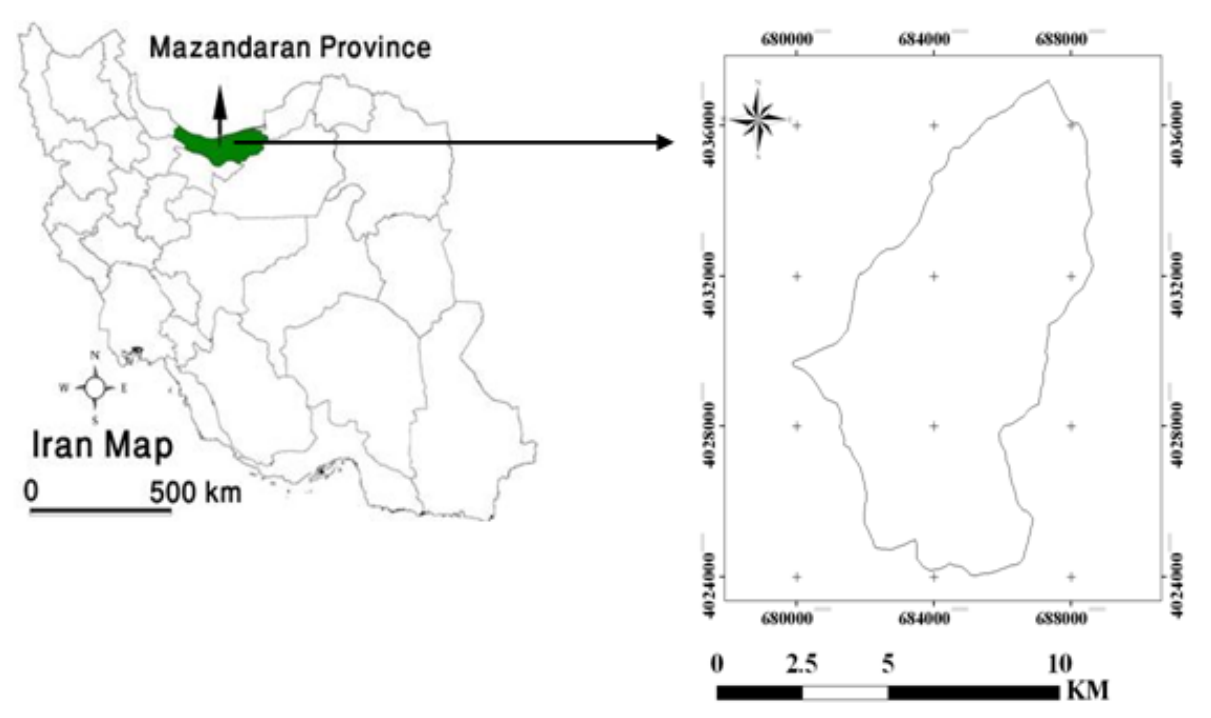

Figure 1. Study area

\subsubsection{Landslide Inventory Map}

The landslide inventory map generation involved the following steps: a) the locations indicating landslide events were recognized on aerial photos; b) landslide indications were verified using field survey by GPS; c) the manifested landslides were mapped on topographic sheets; and d) The landslide occurrences were digitized as polygon layer in ArcGIS.

\subsubsection{Land Component}

According to lee (2005), soil properties have significant influence on landslide zonation. Soil map of the study area were obtained from the local organization at scale of 1:25 000, which includes four different land components denoted with 1.5.2, 1.5.3, 2.5.2 and 2.5.4. The characteristics of these land components are presented in Table 1. Classification has been made based on physiographic units. Soil units were then weighted based on depth and drainage conditions (see Figure 2A).

\subsubsection{Slope and Aspect}

The percent slope map was derived from digital elevation model (DEM) in four classes by using the slope tool and the Raster calculator in Spatial Analyst. The slope of the study area ranges from $0 \%$ to $86 \%$. Slope classes were identified based on practical applications and land suitability. Aspect map were generated from DEM in 
five classes including north $(\mathrm{N})$, south $(\mathrm{S})$, east $(\mathrm{E})$, west $(\mathrm{W})$ and plateau area (F) with no aspect (see Figure 2B and $2 \mathrm{~F}$ ).

Table 1. Major factors and coding approach for homogeneous unites

\begin{tabular}{lccccc}
\hline \multirow{2}{*}{ Factor } & \multicolumn{5}{c}{ Cod of classes } \\
\cline { 2 - 6 } & 1 & 2 & 3 & 4 & 5 \\
\hline Soil & 1.5 .2 & 1.5 .3 & 2.5 .2 & 2.5 .4 & \\
Aspect & $\mathrm{N}$ & $\mathrm{E}$ & $\mathrm{S}$ & $\mathrm{W}$ & $\mathrm{F}$ \\
Elevation & $0-291$ & $291-434$ & $434-592$ & $592-890$ & \\
Geology & $\mathrm{Q}_{2}$ & $\mathrm{PLQ}_{\mathrm{CS}}$ & $\mathrm{M}_{2.3}$ m.s.1 & & \\
Slope & $0-8$ & $8-14$ & $14-25$ & $>25$ & \\
Distance from road & $0-100$ & $100-200$ & $200-300$ & $>300$ & \\
landuse & Forest & Cropland & Garden & & \\
\hline
\end{tabular}
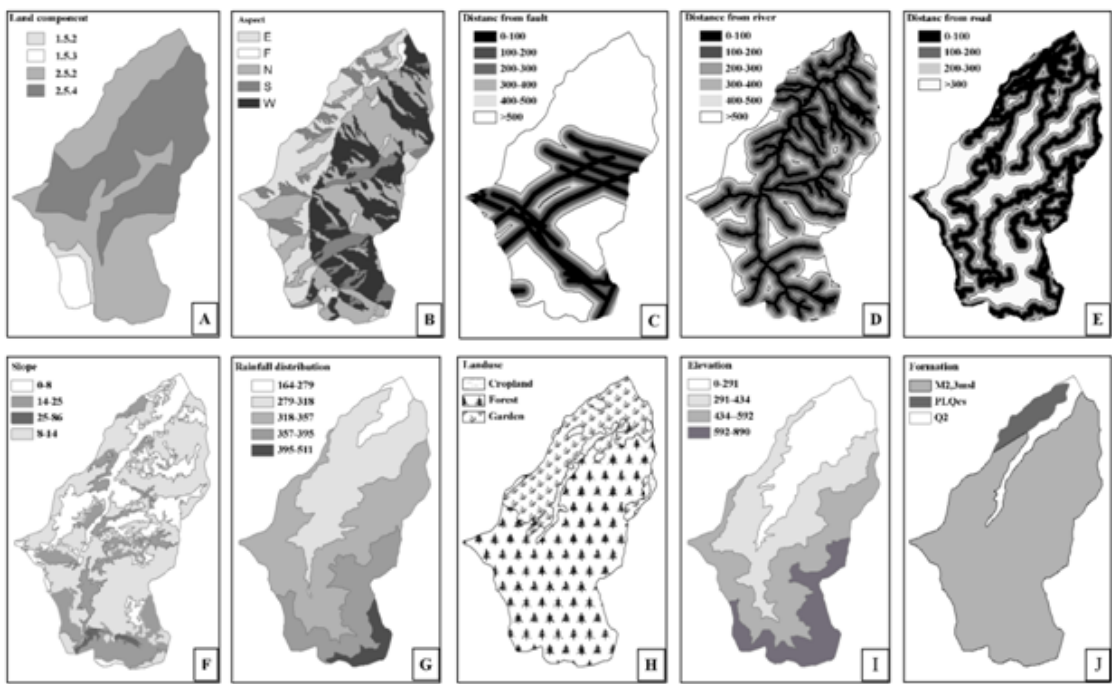

Figure 2. Investigated factors for landslide susceptibility mapping

A) Land component; B) Aspect; C) Distance from fault (m); D) Distance from river (m);

E) Distance from road (m); F) Slope (\%);G) Rainfall (mm); H) Landuse; I) Elevation (m); J) Formation

\subsubsection{Distance from the Roads, Faults and Drainage}

To consider the impact of distance from the roads three type of buffer zone range from 100 to 300 meter were created for existing road map collected from topographic map at scale of 1:50 000 (see Figure 2E).

The same way six buffer zones with $100 \mathrm{~m}$ intervals were created to account the influence of distances from the faults. Distance classes includes 0-100 m, 100-200 m, 200-300 m, 300-400 m, 400-500 and up to $500 \mathrm{~m}$ (see Figure 2C).

Similarly, six buffer zones with $100 \mathrm{~m}$ intervals were generated to account the influence of distance from the drainage network on landslide. Distance classes are included 0-100 m, 100-200 m, 200-300 m, 300-400 m, 400-500 and up to $500 \mathrm{~m}$ (see Figure 2D).

\subsubsection{Rainfall}

The precipitation data of the study area has been obtained from the Ministry of Energy, Government of Iran. Based on these data, rainfall distribution considerably varies through the year in Tajan basin. The mean annual precipitation in Tajan basin ranges from $417 \mathrm{~mm}$ over lowlands to $872 \mathrm{~mm}$ over highlands. Rainfall distribution map was generated using an empirical equation (Equation 1) that relates altitude to the mean annual rainfall over the Tajan basin. 


$$
P=323.2 \log H-53.2
$$

Where $\mathrm{P}$ is the mean annual rainfall $(\mathrm{mm})$ and $\mathrm{H}$ is elevation $(\mathrm{m})$. Then DEM was employed to generate rainfall spatial distribution (see Figure $2 \mathrm{G}$ ).

\subsubsection{Land Use}

It has also been proven that land use play important role in instability of slope in some regions (Jacob, 2000, Anbalagan, 1992, Koukis \& Ziourkas, 1991). However, due to homogeneity of land used in Tajan basin, which is entirely covered with forest we did not take into, account the effect of land use in this study. By using IRS and ETM images, the land use map of the study area was produced and then boundaries were determined in conformity with land use state. As a result of the evaluation, three different land cover are described including mixed of forest and garden, forests, and croplands (see Figure $2 \mathrm{H}$ ).

\subsubsection{Elevation}

This factor is important because in high elevation, precipitation is mostly in the form of snow, which is melting gradually and increasing soil moisture. Therefore, it is more susceptible to susceptible to landslide. To account the elevation in landslide susceptibility map, DEM was classified into four classes (see Figure 2I).

\subsubsection{Geology}

The main source of data related to the geomorphology of an area of land is determined by its lithologic properties (Dai et al., 2001). Geology map for Tajan basin were collected from national geological organization at scale 1:100 000. The permanent lithology units of the study area include $\mathrm{M}_{2.3} \mathrm{~m} . \mathrm{s.1}, \mathrm{PlQ}^{\mathrm{c} . \mathrm{s}}$ and $\mathrm{Q}^{2}$, which:

$\mathrm{M}_{2.3}{ }^{\mathrm{m} . s .1}$ is Miocene sequences consist of marl, sandstone, siltstone, sandy limestone, limy sandstone and mudstone.

$\mathrm{PlQ}^{\text {c.s }}$ is Pliocene and Quaternary sequences consist of conglomerate, sandstone, siltstone, silty marl, marl and mudstone.

$\mathrm{Q}^{2}$ is young terraces and young alluvium.

So these units are very susceptible to landslide (see Figure 2J).

\subsection{Methodology}

In this research, experimental method is applied for assessment of landslide susceptibility implemented trough the following steps:

Preparation of the basic maps:

Survey of Iran 1:25,000 topographical maps were scanned and registered in ERDAS IMAGINE software to prepare the physiographic characteristics of the study area including elevation, slope and aspect. The drainage divides and drainage network were digitized in ArcMap. Contour lines with a $10 \mathrm{~m}$ interval were digitized in ArcMap from the toposheets, and DEM with a $100 \mathrm{~m}$ cell size was generated using TOPOGRID tool in ArcInfo.

Geology, land use and soil maps with climatological characteristics were prepared based on existing source of data collected from local organizations.

Preparation of homogenous units:

Generally, selection of effective factors is based on the nature of the study area and data availability. This is leading to identify the units with similar characteristics. Statistical analysis on observed landslides showed that four factor including distance from channel network, distance from fault and rainfall have not major effect on landslides in this area. Homogenous units were generated using effective layers including land use, lithology, soil, elevation, slope, aspect and distance from the roads. Then these factors were coded from 1 to 5 as showed in Table 2.

Table2 .Susceptibility classes based on Y, value

\begin{tabular}{cc}
\hline Susceptibility of classes & Susceptibility index \\
\hline Very low hazard class & $\mathrm{Y}<-0.0015$ \\
Low hazard class & $-0.0015<\mathrm{Y}<0.01$ \\
Medium hazard class & $0.01<\mathrm{Y}<0.036$ \\
High hazard class & $0.036<\mathrm{Y}<0.061$ \\
Very high hazard class & $0.061<\mathrm{Y}<0.087$ \\
\hline
\end{tabular}


Homogeneous units were identified by combining the data layers which representing the effective parameters. To produce the homogenous units at first, all of the layers converted from raster to vector form in Arcview, then these maps was overlaid using Combine tool in the Transform Grid menu and again the final raster map converted to vector. Finally 158 homogeneous unites were identified.

Quantifying the effective parameters and weighting the factors:

The coded spatial data cannot be used as input variable values directly in the regression analysis to explore the coefficients between the distribution of landslide and the factors in the study area (Xiaoduo et al., 2008). Before modeling the classified factors should be weighted. The weight was taken as input variable values. It was calculated as below:

Quantifying the effective parameters and weighting the factors was based on the area percentage of landslides in the homogenous units where all of the effective parameters were similar excluding one of them that was changing. The area percentage of landslides which depended on each factors were identified by calculating the ratio of observed landslide area to the area of homogeneous units. The weight factor for each class of a specific factor was produced by summing the ratios for each class in different units.

Weight factors were transferred to the quantitative values from 0 to 10 . The class with maximum of the area percentage summation was given the weight of 10 and other classes were given below $(<10)$ based on their proportions.

Multivariate statistical analysis:

Linear regression is a form of multivariate statistical analysis in which observational data are modeled by a function. The function has usually assumed one response variable $Y$ and $\mathrm{m}$ predictor variables $X_{1}, X_{2}, \ldots, X_{m}$ and $n$ observations (Boroushaki \& Malczewski, 2008). In this case study $Y$ is the area percentage of landslides in each homogenous unit, the X's are input independent variables (the weight of classes in effective factors) measured or observed for $n$ homogeneous unit.

Multivariate statistical analysis was then employed to generate multivariate regression model using SPSS software.

Effective vector layers were then converted to raster with 5 meter cell size.

Derived model was applied to calculated landslide susceptibility map in a raster environment.

Raster map was classified in to five quantitative classes range from very low to very high.

\section{Modeling of Landslide Susceptibility}

Multiple regressions with stepwise method in SPSS software was used with seven factors including land use, lithology, soil, elevation, slope, aspect and distance from road against 158 homogeneous units. In this method, independent variables (effective factors) were entered based on its correlation with depend variable (landslide susceptibility). Variables with greater correlation are entered earlier and variables with lower correlation are eliminated. Eventually a numerical model of landslide susceptibility zonation is formed as showed in equation 2 .

$$
Y=0.005 \times 1+0.003 \times 2+0.004 \times 3+0.004 \times 4+0.002 \times 5-0.093
$$

Where $x_{1}, x_{2}, x_{3}, x_{4}$ and $x_{5}$ are weighted factors of Slope, Distance from road, Elevation, Aspect and Soil, respectively, and $\mathrm{Y}$ is Susceptibility index (the area percentage of landslides).

Landslide susceptibility map was generated with developed model in a raster-GIS environment (see Figure 3). Landslide susceptibility map was classified into five classes with equal interval as shown in Table 3. 


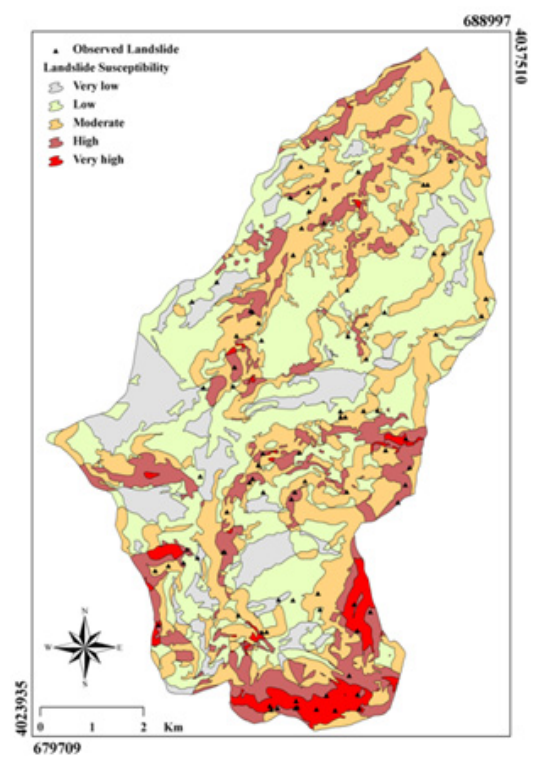

Figure 3. Landslide susceptibility map of the study area

Table 3. The percent area of landslide susceptibility and class

\begin{tabular}{lcc}
\hline Susceptibility class & Susceptibility area (\%) & Observed landslide area (\%) \\
\hline Very low & 11.16 & 6.04 \\
Low & 40.36 & 15.53 \\
Medium & 32.37 & 22.87 \\
High & 12.90 & 26.40 \\
Very high & 3.23 & 29.16 \\
\hline
\end{tabular}

\section{Validation of Landslide Susceptibility Map}

To validate the accuracy of the landslide susceptibility map, observed landslides and susceptibility map was compared. As it evident in Table 3, high percentage of the landslides has been occurred in very high susceptibility area that covers the lower percentage of study area.

\section{Discussion}

In this study area, most of observed landslides have been occurred on slope between $14 \%$ to $25 \%$, which has been already proved, by Neuhauser and Terhorst (2007) and Yalcin (2008). Any landslide has occurred in slopes greater than $25 \%$. It is because of the fact that according to Knopen et al, (2006) in very steep slopes the soil depth and its load are decreased. Considering aspect indicated that most of landslides are occurred in north and west directions, which is related to angle of sun radiation and rainfall. In Iran, most of rainfalls are coming from north-west direction. In addition, North Slope not exposed to radiation, therefore it is more wetly than other aspects. The rate of landslide is increased with elevation. However, in elevation range from zero to 291 meters (elevation class 1) the rate of landslide is more than classes 2 and 3. It may relate to landuse change (forest to cropland) in lower elevation. According to Yalcin (2008), lithology may have significant influences on landslide; however, in this area lithology was eliminated, because the whole study area extended with almost the same lithology. As experienced by Ayalew and Yamagishi (2005), Ercanoglu and Gokeoglu (2004) and Yalcin (2008) degraded forest and gardens are very susceptible to landslide. They have also experienced that cropland and forest are less susceptible to landslide. However, in this study, those factors were eliminated, because there is no significant change in landuse types.

As mentioned by Duman et al. (2006) and Yalcin (2008) observed landslides confirm that most of events are occurred near or close to the roads. The reason for this may relate to constructing roads with deep trenches. It is also observed that more landslides have occurred in land type 2.5.2, it may relate to low infiltration capacity of this zone, which is a barrier for drainage system. Whereas no landslide has been occurred in land type 1.5.3. It is 
may relate to low slope and high infiltration in this land type.

\section{Conclusion}

In this research elevation factor that cause the landslides were investigated. It was found out that five factors including slope, aspect, distance from the road, elevation and land type are more important than the others. It was also found that human activities such as road constructing accelerate the landslide process. It was concluded that with multivariate regression model interrelation existing between instability factors are more highlighted.

\section{Reference}

Anbalagan, R. (1992). Landslide hazard evaluation and zonation mapping in mountainous terrain. Engineering Geology, 32, 269-277. http://dx.doi.org/10.1016/0013-7952(92)90053-2

Ayalew, L., Yamagishi, H. (2004). The application of GIS-based logistic regression for landslide susceptibility mapping in the Kakuda-Yahiko Mountains, Central Japan. Geomorphology, 65, 15-31. http://dx.doi.org/10.1016/j.geomorph.2004.06.010

Baeza, C., \& Corominas, J. (2001). Assessment of shallow landslide susceptibility by means of multivariate statistical techniques. Earth Surface Processes and Landforms, 26, 1251-1263. http://dx.doi.org/10.1002/esp.263

Boroushaki, S., \& Malczewski, J. (2008). Implementing an extension of the analytical hierarchy process using ordered weighted averaging operators with fuzzy quantifiers in ArcGIS. Computers \& Geosciences, 34(4), 399-410. http://dx.doi.org/10.1016/j.cageo.2007.04.003

Carrara, A. (1983). Multivariate models for landslide hazard evaluation. Mathematical Geology, 15, 403-426. http://dx.doi.org/10.1007/BF01031290

Carrara, A., Cardinali, M., Detti, R., Guzzetti, F., Pasqui, V., \& Reichenbach, P. (1991). GIS tecniques and statistical models in evaluating lanslide hazard. Earth Surface Processes and Landforms, 16, 427-445. http://dx.doi.org/10.1002/esp.3290160505

Carrara, A., Cardinali, M., \& Guzzetti, F. (1992). Uncertainty in assessing landslide hazard and risk. ITC Journal, 2, 172-183.

Carrara, A., Cardinali, M., Guzzetti, F., \& Reichenbach, P. (1999). Use of GIS technology in the prediction and monitoring of landslide hazard. Natural Hazards, 20, 117-135. http://dx.doi.org/10.1023/A:1008097111310

Casadei, M., Dietrich, W. E., \& Miller, N. L. (2003). Testing a model for predicting the timing and location of shallow landslide initiation in soil-mantled landscapes. Earth Surface Processes and Landforms, 28, 925-950. http://dx.doi.org/10.1002/esp.470

Cevik, E., \& Topal, T. (2003). GIS-based landslide susceptibility mapping for problematic segment of natural gas pipeline, Hendek (Turky). Environmental Geology, 44, 949-962. http://dx.doi.org/10.1007/s00254-003-0838-6

Chung, C. F., \& Fabbri, A. G. (1999). Probabilistic prediction models for landslide hazard mapping. Photogrammetric Engineering and Remote Sensing (PE\&RS), 65(12), 1388-1399.

Chung, C. F., Fabbri, A. G., \& Van Westen, C. J. (1995). Multivariate regression analysis for landslide hazard zonation. Geographical Information Systems in Assessing Natural Hazards (pp. 107-133). Netherlands: Kluwer Academic Publishers, Dordrecht.

Chung, C. F., Fabbri, A. G. (2001). Prediction models for landslide hazard using fuzzy set approach. In: Marchetti, M., Rivas, V. (Eds.). Geomorphology and Environmental Impact Assessment (pp. 31-47). Rotterdam: A.A. Balkema.

Clerici, A., Perego, S., Tellini, C., \& Vescovi, P. (2002). A procedure for landslide susceptibility zonation by the $\begin{array}{llll}\text { conditional analysis } \quad \text { method. } & \text { Geomorphology, }\end{array}$ http://dx.doi.org/10.1016/S0169-555X(02)00079-X

Dai, E. C., Lee, C. F., Li, J., \& Xu, Z. W. (2001). Assessment of landslide susceptibility on the natural terrain of Lantau Island, Hong Kong. Environmental Geology, 43, 381-391.

Duman, T. Y., Can, T., Gokceoglu, C., Nefeslioglu, H., \& Sonmez, H. (2006). Application of logistic regression for landslide susceptibility zoning of Cekmece Area, Istanbul, Turky, Environment Geology, 51, 241-256. http://dx.doi.org/10.1007/s00254-006-0322-1

Ercanoglu, M., Gokceoglu, C., \& Van Asch, T. H. W. J. (2004a). Landslide susceptibility zoning north of Yenice 
(NW Turkey) by multivariate statistical techniques. Natural Hazards, 32, 1-23. http://dx.doi.org/10.1023/B:NHAZ.0000026786.85589.4a

Ercanoglu, M., \& Cokceoglu, C. (2004b). Use of fuzzy relations to produce landslide susceptibility map of a landslide prone area (West Black Sea Region, Turky). Engineering Geology, 75, 229-250. http://dx.doi.org/10.1016/j.enggeo.2004.06.001

Glenn, N. F., Streutker, D. R., Chadwick, D. J., Thackray, G. D., \& Dorsch, S. J. (2006). Analysis of LiDAR-derived topographic information for characterizing and differentiating landslide morphology and activity. Geomorphology, 73, 131-148. http://dx.doi.org/10.1016/j.geomorph.2005.07.006

Gorsevski, P. V., Gessler, P. E., Boll, J., Elliot, W. J., \& Foltz, R. B. (2006). Spatially and temporally distributed modeling of landslide susceptibility. Geomorphology, $\quad 80, \quad 178-198$. http://dx.doi.org/10.1016/j.geomorph.2006.02.011

Jade, S., \& Sarkar, S. (1993). Statistical models for slope stability classification. Engineering Geology, $36,91-98$. http://dx.doi.org/10.1016/0013-7952(93)90021-4

Koukis, G., \& Ziourkas, C. (1991). Slope instability phenomena in Greece: A statistical analysis. Bull Int Assoc Engineering Geology, 43, 47-60. http://dx.doi.org/10.1007/BF02590170

Komac, M. (2006). A landslide susceptibility model using the analytical hierarchy process method and multivariate statistics in perialpine Slovenia. Geomorphology, 74, 17-28. http://dx.doi.org/10.1016/j.geomorph.2005.07.005

Knapen, A., Kitutu, M. G., Poesen, J., Breugelmans, W., Deckers, J., \& Muwanga, A. (2006). Landslides in a densely populated county at the footslopes of Mount Elgon (Uganda): Characteristics and causal factors. Geomorphology, 73, 149-165. http://dx.doi.org/10.1016/j.geomorph.2005.07.004

Lee, S. (2005). Application and cross-validation of spatial logistic multiple regression for landslide susceptibility analysis. Geoscience, 9, 63-71. http://dx.doi.org/10.1007/BF02910555

Lee, S. (2007). Application and verification of fuzzy algebraic operators to landslide susceptibility mapping, Environmental Geology, 52, 615-623. http://dx.doi.org/10.1007/s00254-006-0491-y

Lee, S., \& Min, K. (2001). Statistical analysis of landslide susceptibility at Yongin, Korea. Environmental Geology, 40, 1095-1113. http://dx.doi.org/10.1007/s002540100310

Lee, S., Ryu, J. H., Won, J. S., \& Park, H. J. (2004). Determination and application of the weights for landslide susceptibility mapping using an artificial neural network. Engineering Geology, 71, $289-302$. http://dx.doi.org/10.1016/S0013-7952(03)00142-X

Mark, R. K., Ellen, S. D. (1995). Statistical assimilation models for mapping debris flow hazard. In: Carrara, A., Guzzetti, F. (Eds.). Geographical Information Systems in Assessing Natural Hazards. (pp. 135-175). Netherlands: Kluwer Academic Publishers, Dordrecht

McCullagh, P., \& Nelder, J. A. (1989). Monographs on Statistics and Applied Probability 37. London: Chapman \& Hall, ( p. 511).

Pachauri, A. K., \& Pant, M. (1992). Landslide hazard mapping based on geological attributes. Engineering Geology, 32, 81-100. http://dx.doi.org/10.1016/0013-7952(92)90020-Y

Pachauri, A. K., Gupta, P. V., \& Chander, R. (1998). Landslide zoning in a part of the Garhwal Himalayas. Environmental Geology, 36, 325-334. http://dx.doi.org/10.1007/s002540050348

Saha, A. K., Gupta, R. P., \& Arora, M. K. (2002). GIS-based landslide hazard zonation in the Bhagirathi (Ganga) valley, Himalayas. International Journal of Remote Sensing, 23, 357-369. http://dx.doi.org/10.1080/01431160010014260

Schmidt, K. H., Beyer, I. (2003). High-magnitude landslide events on a limestone-scarp in central Germany: morphometric characteristics and climatic controls. Geomorphology, 49, 323-342. http://dx.doi.org/10.1016/S0169-555X(02)00193-9

Sinha Y. M., Salocks, C. B., \& Vanderlaan, W. P. (1975). Prolactin and growth hormone levels in different inbred strains of mice: patterns in association with estrous cycle, time of day and perphenazine stimulation. Endocrinol, 97, 1112-1122. http://dx.doi.org/10.1210/endo-97-5-1112

Skempton, A. W. (1953). Soil mechanics in relation to geology. Proceedings of the Yorkshire Geological Society 29, 33-62. http://dx.doi.org/10.1144/pygs.29.1.33 
Suzan, M. L., \& Doyuran, V. (2004). Data driven bivariate landslide susceptibility assessment using geographical information system: A method and application to asarsuyu catchment. Turky Eng. Geol., 71, 303-321. http://dx.doi.org/10.1016/S0013-7952(03)00143-1

Terlien, T. J. (1998). The determination of statistical and deterministic hydrological landslide-triggering thresholds. Environmental Geology, 35, 124-130. http://dx.doi.org/10.1007/s002540050299

Neuhauser, B., \& Terhorst, B. (2007). Landslide susceptibility assessment using weights of evidence applied to a study area at the Jurassic Escarpment (SW-Germany). Geomorphology, 86, 12-24. http://dx.doi.org/10.1016/j.geomorph.2006.08.002

Xiaoduo, P., Hiroyuki, N., Tamosu, N., \& Xiao, Z. H. (2008). A GIS-based landslide hazard assessment by multivariate analysis. Journal of the Japan landslide society, 45(3), 187-195.

Yalcin, A. (2005). An investigation on Ardesen (Rize) region on the basis of landslide susceptibility. PhD Thesis, Karadeniz Technical University, Trabzon, Turkey. (in Turkish).

Yalcin, A. (2008). GIS based landslide susceptibility mapping using analytical hierarchy process and bivariat statistics in Ardesen (Turkey): comparision of results and confirmations. Catena, 72, 1-12. http://dx.doi.org/10.1016/j.catena.2007.01.003 